\title{
ALTERNATIF PEMIDANAAN TERHADAP PELAKU PENYALAHGUNAAN NARKOTIKA DALAM KEBIJAKAN KRIMINAL DI INDONESIA
}

\author{
Ratri Novita Erdianti \\ Fakultas Hukum Universitas Muhammadiyah Malang \\ Jl. Raya Tlogomas No. 246, Dau, Malang \\ Email; ni_ratry@yahoo.com
}

\begin{abstract}
Narcotics crime in Indonesia becomes a problem that until now never ceased. One of the problems is the increasing number of narcotics abusers. In our country, narcotic users/narcotics addicts can already be said as a criminal offender. In the Narcotics Act no. 35 of 2009 explained that what are meant by Narcotics Abusers are people who use Narcotics without rights or against the law. Persons who use narcotics unlawfully and unlawfully herein may be classified as addicts and distributors who use and conduct circulation. In the narcotics law, a drug addict victim of narcotics must undergo medical rehabilitation and social rehabilitation. But in reality, the article for narcotics abusers is more directed at other positions in the positions of dealers whose criminal consequences become imprisonment. This is for the author less appropriate. So that efforts made in solving cases of perpetrators of criminal acts become part of criminal policy in the context of the prevention of narcotics crime. The problem that the writer raised is about the relevance of criminal prison for narcotics abusers with the purpose of punishment and how the application of alternative punishment against narcotics abusers from the perspective of criminal policy. This study was conducted using normative juridical, which examines Law no. 35 of 2009 which regulates the form of punishment for the perpetrators of narcotics abuse is associated with the theories in criminal law
\end{abstract}

Keywords: Abuser, Narcotics Crime, Criminal Policy

\begin{abstract}
Abstrak
Tindak pidana narkotika di Indonesia menjadi permasalahan yang sampai sekarang tidak pernah ada habisnya. Salah satu permasalahannya adalah meningkatnya jumlah penyalahguna narkotika. Di negara kita, pengguna narkotika / pecandu narkotika sudah dapat dikatakan sebagai seorang pelaku tindak pidana. Dalam UU Narkotika No. 35 Tahun 2009 dijelaskan bahwa yang dimaksud dengan Penyalahguna narkotika adalah orang yang menggunakan Narkotika tanpa hak atau melawan hukum. Orang yang menggunakan narkotika secara tanpa hak dan melawan hukum di sini dapat diklasifikasikan sebagai pecandu dan pengedar yang menggunakan dan melakukan peredaran. Dalam UU narkotika, seorang pecandu korban penyalagunaan narkotika wajib menjalani rehabilitasi medis dan rehabilitasi sosial. Namun realitasnya, pasal bagi penyalahguna narkotika lebih banyak diarahkan pada posisi lain yakni dalam posisi pengedar yang konsekuensi pidananya menjadi pidana penjara. Hal tersebut yang bagi penulis kurang sesuai. Sehingga upaya yang dilakukan dalam menyelesaikan perkara pelaku tindak pidana menjadi bagian kebijakan criminal dalam rangka penanggulangan tindak pidana narkotika. Adapun permasalahan yang penulis angkat yakni tentang relevansi pidana penjara bagi penyalahguna narkotika dengan tujuan pemidanaan serta bagaimana penerapan alternative pemidanaan terhadap pelaku penyalahguna narkotika
\end{abstract}


dari perspektf kebijakan criminal. Penelitian ini dilakukan dengan menggunakan yuridis normatif, yang mana mengkaji UU No. 35 Tahun 2009 yang mengatur bentuk bentuk pemidanaan bagi pelaku penyalahguna narkotika dikaitkan dengan teori-teori dalam hukum pidana.

\section{Kata kunci : Penyalahguna, Tindak Pidana Narkotika, Kebijakan Kriminal}

\section{A. PENDAHULUAN}

Indonesia merupakan salah satu negara yang ada didunia, yang menjadi salah satu tujuan peredaran narkotika. Hal ini dapat dibuktikan dengan banyaknya kasus yang diungkap aparat penegak hukum terkait jaringan peredaran narkoba yang sudah berskala internasional. Dengan adanya peredaran narkotika yang semakin menjamur tersebut, maka dalam hal ini berbagai elemen yang berkaitan harus berupaya untuk segera melakukan pembrantasan. Hal lain, yang tidak kalah pentingnya adalah bukan hanya permasalahan peredaran narkotika yang terjadi di masyarakat, namun juga berkenaan dengan banyaknya masyarakat yang terjebak sebagai pengguna narkotika yang dilakukan secara meawan hukum.

Di Indonesia, pengguna narkotika / pecandu narkotika sudah dapat dikatakan sebagai seorang pelaku tindak pidana. Dalam UU Narkotika No. 35 Tahun 2009 dijelaskan bahwa yang dimaksud dengan Penyalahguna narkotika adalah Penyalah Guna adalah orang yang menggunakan Narkotika tanpa hak atau melawan hukum. Orang yang menggunakan narkotika secara tanpa hak dan melawan hukum di sini dapat diklasifikasikan sebagai pecandu dan pengedar yang menggunakan dan melakukan peredaran.

Dalam kedudukan penyalahgunaan narkotika tersebut, UU narkotika memberikan dua bentuk pemidanaan yang berbeda, dalam kondisi sebagai seorang pecandu, UU menyatakan, "Pecandu Narkotika dan korban penyalagunaan narkotika wajib menjalani rehabilitasi medis dan rehabilitasi sosial." Sedangkan bentuk lainnya, bahwa orang yang tanpa hak dan melawan hukum menanam, memelihara, memiliki, menyimpan, menguasai, atau menyediakan, hukumannya adalah pidana penjara.. Hal tersebut dituangkan dalam pasal 127 terkaiy kedudukan penyalahguna narkotika dalam UU tersebut, dijelaskan bahwa " Setiap Penyalah Guna Narkotika Golongan I bagi diri sendiri dipidana denga pidana penjara paling lama 4 (empat) tahun;. Narkotika Golongan II bagi diri sendiri dipidana dengan pidana penjara paling lama 2 (dua) tahun; dan Narkotika Golongan III bagi diri sendiri dipidana dengan pidana penjara paling lama 1 (satu) tahun.",namun dalam menjatuhkan putusan pidana tersebut hakim harus memperhatikan bahwa jika penyalahgunaa narkotika tersebut adalah korban, maka wajib mendapatkan rehabilitas sosial maupun medis.

Jika dilihat dari kasus yang marak terjadi, banyak para pengguna narkotika yang terbukti bersalah menyalahgunakan narkotika akan diarahan pada bentuk pemidanaan pidana penjara tanpa melalui peroses rehabilitasi medis mau rehabilitasi sosial. Dalam hal ini peneliti melihat, bahwa proses penegakan hukum yang dilakukan kepada pengguna tidak boleh disamakan dengan pelaku tindak pidana narkotika yang lain. Hal ini berarti, bahawa dalam hal pengguna narkotika yang menyalah gunakan narkotika untuk dirinya sendiri tidak bisa disamakan dengan penyalahguna narkotika yang dia menggunakan untuk dirinya sendiri serta 
juga menyediakan untuk orang lain baik itu untuk dijual ataupun tidak dijual. Peneliti berpendapat bahwa, dalam hal pengguna meunggunakan untuk diri sendiri berarti posisi korban merupakan dirinya sendiri, berbeda dengan ketika terdapat orang lain yang menjadi korban dari penyalahgunaan narkotika.

Penulis coba melihat banyak putusan hakim ditingkat PN yang memutus kasus Narkotika yang menurut penulis cukup besar. Sebagian besar yang penulis lihat, kebanyakan pelaku penyalahgunaan narkotika, dijatuhi hukuman pidana penjara oleh hakim, dan bukan memberikan rehabilitasi. Penulis memandang, bahwa dengan pemidanaan yang mengarah pada pidana penjara bukannya rehabilitasi ini ika bisa dipicu dari jaksa yang menggunakan pasal yang bukan penyalahgunaan narkotika melainkan mengarah pada penjual ataupun pengedar.

Dengan demikian, hal yang terjadi adalah perbedaan pemikiran antara para aparat penegak hukum yang nantinya akan menimbulkan penanganan penyalahguna narkotika yang berbeda pula. Peneliti melihat, tidak jarang penyidik menggunakan pasal yang tidak seharusnya diberikan kepada pecandu dan korban penyalahgunaan narkotika. Jaksa Penuntut Umum pun akhirnya melanjutkan tuntutan yang sebelumnya sudah disangkakan oleh penyidik,. Selanjutnya yang kemudian hal itu berujung vonis pidana penjara oleh Pengadilan kepada para pecandu dan korban penyalahgunaan narkotika bukannya rehabilitasi terhadap penyalahgunaan narkotika .

Terkait hal tersebut, selama ini peneliti melihat bahawa dalam memutus perkara pidana yang melibatkan penyalahguna narkotika dengan korban dirinya sendiri, hakim lebih memilih menggunakan pidana penjara untuk pemidanaan bagi terdakwa,hal ini menurut peneliti kurang cocok dijatuhkan. Dalam menentukan hukuman terhadap pelaku penyalahguna narkotika, hakim cenderung memilih pidana penjara dalam menjatuhkan putusan pidana, hal ini yang menurut peneliti kurang sesuai karena dalam hal ini seharusnya hakim dalam menjatuhkan pidana juga mementingkan aspek tujuan pemidanaan yang ingin dicapai sehingga tujuan kebijakan kriminal akan terlaksana yakni menanggulangi tindak pidana narkotika.

Penulis mengambil beberapa putusan pidana oleh hakim pada tahun 2017 , yang memutus pidana penjara bagi pelaku penyalahgunaan narkotika tetapi tidak menggunakan rehabilitasi sebagai upaya untuk memperbaiki pelaku, hal ini lah yang menjadi salah satu latar belakang bagi penulis untuk melakukan penelitian ini . Dalam putusan pertama PN MALANG Nomor 441/Pid.Sus/2017/PN Mlg Tahun 2017 ${ }^{1}$, Pengadilan menyatakan terdakwa telah terbukti secara sah dan meyakinkan bersalah melakukan tindak pidana tanpa hak atau melawan hukum menyimpan dan menguasai Narkotika Golongan I bukan tanaman". hakim menjatuhkan pidana terhadap terdakwa tersebut oleh karena itu dengan pidana penjara selama : 5 (lima) tahun 6 (enam) bulan dan denda sebesar Rp 800.000.000,- (delapan ratus juta rupiah) dengan ketentuan apabila denda tidak dibayar diganti dengan pidana penjara selama 3 (tiga) bulan

Putusan hakim yang kedua yakni Putusan PN MALANG Nomor 452/Pid.Sus/2017/PN

${ }^{1}$ Direktori Mahkamah Agung,diakses pada tanggal 10 Oktobeer 2017 
Mlg Tahun 2017. ${ }^{2}$ Dalam putusan dinyatakan Menyatakan terdakwa terbukti secara sah dan meyakinkan bersalah melakukan tindak pidana : " tanpa hak memiliki Narkotika Golongan I bukan tanaman". Hakim menjatuhkan pidana kepada terdakwa oleh karena itu dengan pidana penjara selama 4 (empat) tahun dan 6 (enam) bulan dan denda sebesar Rp.800.000.000,(delapan ratus juta rupiah) jika denda tersebut tidak dibayar harus diganti dengan pidana penjara selama 3 (tiga) bulan .

Putusan ketiga yakni Putusan PN MALANG Nomor 313/Pid.Sus/2017/PN Mlg Tahun $2017,{ }^{3}$ Menyatakan Terdakwa telah terbukti secara sah dan meyakinkan bersalah melakukan tindak pidana : "menyalahgunakan narkotika golongan I bagi diri sendiri " . Hakim menjatuhkan menjatuhkan pidana terhadap terdakwa oleh karena itu dengan pidana penjara selama 1 (satu) tahun .

Putusan diatas adalah tiga putusan dari sekian banyak putusan hakim tentang penyalahgunaan narkotika bagi diri sendiri yang pada akhirnya dijatuhi hukuman penjara poleh Hakim. Perlu diketahui pidana penjara adalah salah satu bentuk pidana yang sering digunakan hakim dalam memutus perkara, yang sebenarnya juga memiliki kelamahan dalam penerapannya. Bagi pecandu atau penyalahguna narkotika menjadi tidak sesuai dengan diberikannya pidana penjara kepada meraka. Selain mendapat tetapi penghuni didalamnya yakni ada proses sosialisasi antar narapidana. Dalam proses sosialisasi ini, sangat dimungkinkan bagi narapidana akan mendapatkan ilmu dari narapidana lainnya yang nantinya dikhawatirkan akan menjadi ilmu dan mugkin juga dapat dipraktekkan ketika narapidana lain keluar. Proses sosialisasi ini dapat dikatakan akan menjadi sekolah bagi para "penjahat" untuk berbagi ilmu kejahatan.

Dalam halnya pecandu / penyalahguna yang menjadi narapidana, tujuan pemidanaan akan tidak bisa tercapai mengingat dalam hak ini pelaku penyalhgunaan ini pada dasarnya adalah korban, dan ketika mereka berada dalam satu ruangan dengan pelaku tindak pidana lainnya maka lebih banyak efek negatif yang akan muncul. Seharusnya pidana penjara menjadi "obat" bagi narapidana untuk mnejadi lebih baik maka sangat dimungkinkan jhal tersebut tidak akan terwujud.

Dari latar belakang tersebut, peneliti tertarik untuk mengambil permasalahan yaitu :a) Bagaimana relevansi pidana penjara bagi pelaku penyalahgunaan narkotika dengan tujuan pemidanaan di Indonesia; serta b) Bagaimana penerapan alternatif pemidanaan bagi pelaku penyalahgunaan narkotika sebagai upaya dalam kebijakan kriminal di Indonesia

\section{B. PEMBAHASAN}

Pidana penjara merupakan salah satu pidana pokok di Indonesia, pidana ini merupakan pilihan pidana pokok yang paling sering digunakan untuk menangani kasus tindak pidana . Dalam kasus penyalahgunaan narkotika yang penulis angkat di latarbelakang diatas, putusan pidana dalam ketiga putusan itu adalah pidana penjara.

Jika dilihat, yang dimaksud dengan pidana penjara adalah pidana perampasan kemerdekaan didalam lembaga pemasyarakatan yang dalam kurun waktu tertentu. Dalam

\footnotetext{
${ }^{2}$ Direktori Mahkamah Agung, diakses pada tanggal 5 November 2017

${ }^{3}$ Direktori Mahkamah Agung, diakses tanggal 5 November 2017
} 
pelaksanaannya, penulis melihat bahwasannya dalam kasus penyalahgunaan narkotika, penulis melihat bahwasannya pidana penjara jika dijatuhkan kepada pelaku penyalahgunaan narkotika belumlah memenuhi tujuan pemidanaan yang hendak dicapai. Perlu diketahu, bahwa di Indoensia, tidak ada pembedaan lembaga pemasyarakatan bagi pelaku kejahatan dengan berbagai bentuk kejahatan. Sehingga proses pembinaan yang dilakukan kepada semua pelaku terpidana dalam lembaga pemasyarakatan tidak akan dibedakan berdasarkan jenis kejahatannya. Dalam kaitannya dengan tindak pidana penyalahgunaan narkotika , kiranya perlu dilakukan suatu tindakan atau treatment yang mana tindakan tersebut sangat berkaitan dengan pemulihan terpidana dari pengaruh narkotika.

Kita tahu bahwa dalam penyalahgunaan narkotika, yang bertindak sebagai pelaku dan korban adalah dirinya sendiri, sehingga dalam hal ini akan menjadi kurang tepat jika tidak dilakukan suatu pidana yang berbenuk tindakan dalam hal ini rehabilitasi medis dan sosial bagi pelaku.

Berkenaan dengan pemberiaan pidana, diperlukan kejelian hakim sebagai pelaksana dari akhir penegakan hukum sebagai cara dalam menanggulangi kejahatan yang ada di masyarakat. Hakim memiliki pedoman dalam menjatuhkan putusan pidana kepada masyarakat. Jelas Bahwa Pengadilan mempunyai kedudukan penting dalam sistem hukum kita, karena ia melakukan fungsi yang pada hakikatnya melengkapi ketentuan hukum tertulis melalui Pembentukan Hukum (Rechtvorming) dan penemuan hukum (Rechtvinding). ${ }^{4}$

Dalam penjatuhan putusan pidana dalam tindak pidana ,hakim juga harus mempertimbangkan pidana yang akan diberikan kepada terdakwa sesuai dengan tindak pidana yang dilakukan. Dan pemberian pidana tersebut juga harus mengarah kepada masa depan dari pada terdakwa dan juga masyarakat. Fungsi utama seorang hakim adalah memberikan putusan terhadap perkara yang diajukan padanya, dimana dalam perkara pidana hal itu tidak lepas dari sistem pembuktian negatif, yang pada prinsipnya menentukan bahwa suatu hak atas peristiwa atau kesalahan dianggap telah terbukti, disamping adanya alat-alat bukti menurut UU juga ditentukan keyakinan hakim yang dilandasi dengan integritas moral yang baik. Jadi putusan hakim tidak hanya didasarkan semata-mata pada ketentuan yuridis saja melainkan juga didasarkan hati nurani. ${ }^{5}$

Tongat menyatakan bahwa "Pidana perampasan kemerdekaan semakin tidak disukai baik atas pertimbangan kemanusian, pertimbangan filosofis pemidanaan maupun pertimbangan ekonomis." ${ }^{\prime 6}$ Terkait pemberian pidana, pilihan pidana penjara merupakan pilihan yang sering diberikan kepada terdakwa ternyata telah memberikan permasalahan baru dalam proses pemidanaan dalam lembaga pemasyarakatan seperti yang penulis kemukakan diatas. Menurut Barda nawawi Arief, terkait pelaksanaan pidana penjara terdapat banyak kritikan ditujukan terhadap pidana penjara. Secara garis besar, kritik tersebut terdiri dari kritik yang moderat dan kritik yang ekstrem. Kritik moderat pada intinya masih mempertahankan pidana penjara namun penggunaannya dibatasi, sedangkan kritik yang ekstrim menghendaki penghapusan

\footnotetext{
${ }^{4}$ Pontang, Pembentukan Hukum melalui Putusan Pengadilan Dalam Perkara Pidana , ,Bandung,, Alumni,2005. Hal.15

${ }^{5}$ Ahmad Rifai, Penemuan Hukum Oleh Hakim Dalam Perspektif Hukum Progresif, Sinar Grafika, Jakarta, 2010. Hal 103.

${ }^{6}$ Tongat, Pidana Kerja Sosial dalam Hukum Pidana Di Indonesia, Jakarta, Djambatan, 2002, hlm.4
} 
pidana penjara. ${ }^{7}$

Dalam lembaga pemasyarakatan, terdapat berbagai macam pelaku tindak pidana yang sangat dimungkinkan untuk berinterkasi. permasalahan lain yang muncul terkait pemberian pidana penjara kepada pelaku tindak pidana penjara adalah terjadi pada saat narapidana berada di Lembaga Pemasyarakatan (LP). Seperti yang kita ketahui bahwa di Negara Indonesia ini, narapidana yang tinggal di dalam LP ini tidak dibeda-bedakan menurut berat ringannya tindak pidana yang dilakukan hanya dibedakan menurut jenis kelamin juga masih anak-anak atau sudah dewasa narapidana tersebut sehingga narapidana baik narapidana tindak pidana ringan dengan narapidana tindak pidana berat yang berada dalam LP berkumpul menjadi satu, bahkan tidak terdapat pembedaan terhadap sebuah jenis tindak pidana yang satu dengan tindak pidana yang lainnya.

Di dalam proses pemasyarakatan dikenal istilah prisonisasi. Keadaan LP oleh Clemmer, dilukiskan sebagai suatu system social yang informal yang disebut sebagai sub kulur narapidana. Sub kultur narapidana ini memepunyai pengaruh yang besar terhadap kehidupann individuak dari masing-masing narapidan, khususnya proses sosialisasi narapidana tersebut ke dalam masyarakat narapidana yang disebut prisonisasi ${ }^{8}$ Dari istilah , maka dipahami bahwa prisonisasi dimaksudkan sebagai proses penyerapan tata cara kehidupan di dalam penjara. Proses penyerapan tersebut dilakukan dengan proses belajar (learning process) dalam berinteraksi antar sesama narapidana.

Dengan demikian, untuk menentukan tinggi rendahnya pengaruh tata cara kehidupan dalam penjara juga akan berpengaruh terhadap ada tidaknya kontak interpersonal antar narapidana. Perlu kita ketahui Kultur kehidupan narapidana mempunyai pengaruh yang besar terhadap kehidupan individual narapidana, sehingga setiap penghuni penjara (narapidana) akan menjalani proses penyesuaian dengan kehidupan di dalamnya. Yang perlu dikhawatirkan dari proses sosialisasi antara narapidana yakni terdapat proses belajar (learning process) dalam berinteraksi antar sesama narapidana. Dengan demikian, untuk menentukan tinggi rendahnya pengaruh tata cara kehidupan dalam penjara ditentukan oleh erat tidaknya kontakl antar narapidana.

Jika dibandingkan,antara penjatuhan pidana penajara dengan rehabilitasi medis bagi pelaku penyalhagunaan narkotika untuk dirinya sendiri, maka pendapat penulis nahwa akan lebih tepat jika dilakukan rehabilitasi medis. Dalam korelasinya denga tujuan pemidanan, bahwa tujuan pemidanaan yang hendak dicapai adalah salah satunya menanggulangi kejahatan dengan mencegak terjadinya tindak pidana dan memperbaii diri pelaku. Dalam proses rehabilitasi medis dan sosial bagi pelaku, maka pada menurut penulis kedua bentuk rehabilitasi tersebut akan sesuai dengan dua capaian dalam tujuan pemidanaan. Dalam rehabilitasi medis, maka tindakan treatment dilakukan dengan tujuan agar memperbaiki pelaku agar tidak menggunakan narkotika kembali. Sedangkan jika pelaku dimasukkan kedalam LP, akan menjadi pertanyaan bahwa bagaimana proses pembinaan akan dapat dilakukan jika terpidana tidak diberikan treatment sesuai dengan kebutuhannya.

Penulis berpenddapat bahwa penyalahgunaan narkotika tidak bisa disamakan dengan

\footnotetext{
${ }^{7}$ Barda Nawawi Arief, Kapita Selekta Hukum Pidana, Bandung, Citra Aditya Bakti, 2010, hlm. 33

${ }^{8}$ Muladi, Lembaga Pidana Bersyarat, Bandung, PT. Alumni, 2004. Hal. 141
} 
kejahatan lainnya seperti mencuri, membunuh, menganiaya dan laiinya yang bisa dilikakukan pembinaan didalam Lemabga Pemasyarakatan. Dalam penyalahgunaan narkotika, akan berkaitan dengan kondisi pikiran atau fisik yang jika sudah menggunakan narkotika maka diperlukan suatu pengobatan agar pelaku sembuh dari ingin mengggunakan narkotika bahkan sampai ketergantungan narkotika.

Yang menarik untuk penulis kaji adalah, Seringkali kita melihat bahwa putusan hakim terhadap penyalahgun narkotka didasarkan pada dakwaan terhadap pelaku yakni melanggar pasal 112 UU No. 35 tahun 2009 tentang Narkotika yakni (1) Setiap orang yang tanpa hak atau melawan hukum memiliki, menyimpan, menguasai, atau menyediakan Narkotika Golongan I bukan tanaman, dipidana dengan pidana penjara paling singkat 4 (empat) tahun dan paling lama 12 (dua belas) tahun dan pidana denda paling sedikit Rp800.000.000,00 (delapan ratus juta rupiah) dan paling banyak Rp8.000.000.000,00 (delapan miliar rupiah). (2) Dalam hal perbuatan memiliki, menyimpan, menguasai, atau menyediakan Narkotika Golongan I bukan tanaman sebagaimana dimaksud pada ayat (1) beratnya melebihi 5 (lima) gram, pelaku dipidana dengan pidana penjara seumur hidup atau pidana penjara paling singkat 5 (lima) tahun dan paling lama 20 (dua puluh) tahun dan pidana denda maksimum sebagaimana dimaksud pada ayat (1) ditambah 1/3 (sepertiga).

Penulis melihat dari banyakya kasus penyalahgunaan tersebut, bahwa untuk dapat dilakukan penjatuhan pidana rehabilitasi maka , terdakwa hanya bisa jika dia dakwa dengan mengggunakan pasal 127 UU No. 35 Tahun 2009 yakni Setiap Penyalah Guna:

a) Narkotika Golongan I bagi diri sendiri dipidana dengan pidana penjara paling lama 4 (empat) tahun;

b) Narkotika Golongan II bagi diri sendiri dipidana dengan pidana penjara paling lama 2 (dua) tahun; dan

c) Narkotika Golongan III bagi diri sendiri dipidana dengan pidana penjara paling lama 1 (satu) tahun.

2) Dalam memutus perkara sebagaimana dimaksud pada ayat (1), hakim wajib memperhatikan ketentuan sebagaimana dimaksud dalam Pasal 54, Pasal 55, dan Pasal 103.

3) Dalam hal Penyalah Guna sebagaimana dimaksud pada ayat (1) dapat dibuktikan atau terbukti sebagai korban penyalahgunaan Narkotika, Penyalah Guna tersebut wajib menjalani rehabilitasi medis dan rehabilitasi sosial.

Dari beberapa putusan yag coba penulis kaji, hakim memutus bedasarkan dakwaan jaksa yang telah menggunakan pasal 112 sehingga tidak mungkin bagi hakim akan menjatuhkan putusan pidana berupa rehabilitasi medis jika dalam dakwaan, jaksa tidak menggunakan pasal 127.

Jika ditelaah, secara substansi pasal 112 UU No. 35 Tahun 2009 penulis melihat bahwasannya yang dimaksud dengan Setiap orang yang tanpa hak atau melawan hukum memiliki, menyimpan, menguasai, atau menyediakan mempunyai makna yang sangat luas sekali. Bahwasanya kata memiliki, menyimpan, menguasai atau menyedeiakan bisa 
bermakna barang itu dalam penguasan pelaku dan hanya digunakan untuk pelaku, sehingga dalam hal ini pelaku bisa dikatakan korban untuk dirinya sendiri. Selain itu makna kata menguasai dan sebagainya bisa juga diartikan untuk menguasai yang peruntukannnya bukan untuk diri sendiri atau untuk orang lain sehingga dapat dilkatakan terdapat korban lain. Dengan demikian, pemaknaan kata memiliki, menguasai dan menyediakan memiliki pemaknaan yang kurang jelas peruntukkannya.

Dalam ketiga kasus putusan diatas, barang narkotika ternayata digunakan untuk diri sendiri sehingga bisa dikatakan bahwa tidak ada korban lain selain pelaku. Sehingga menurut penulis , kasus tersebut lebih tepat jika menggunakan pasal 127 yang konsekuensinya adalah bisa dilakukan rehabilitasi medis.Tiga kasus diatas adalah sebagaian kecil dari banyaknya kasus penyalahgunaan narkoba yang hanya diputus pidana penjara.

Seperti dijelaskan pada pasal Pasal 54 Pecandu Narkotika dan korban penyalahgunaan Narkotika wajib menjalani rehabilitasi medis dan rehabilitasi sosial. Sejalan dengan pasal 54, dalam Pasal 103 dijelaskan bahwa

(1) Hakim yang memeriksa perkara Pecandu Narkotika dapat:

a) memutus untuk memerintahkan yang bersangkutan menjalani pengobatan dan/atau perawatan melalui rehabilitasi jika Pecandu Narkotika tersebut terbukti bersalah melakukan tindak pidana Narkotika; atau;

b) menetapkan untuk memerintahkan yang bersangkutan menjalani pengobatan dan/atau perawatan melalui rehabilitasi jika Pecandu Narkotika tersebut tidak terbukti bersalah melakukan tindak pidana Narkotika.

(2) Masa menjalani pengobatan dan/atau perawatan bagi Pecandu Narkotika sebagaimana dimaksud pada ayat (1) huruf a diperhitungkan sebagai masa menjalani hukuman.

Dari kedua pasal diatas dapat dilihat bahwa terdapat alternative pemidanaan selain pidana penjara yang bisa dijatuhkan kepada pelaku penyalahgunaan narkotika yang mana hal tersebut dilakukan sebagai bentuk treatment bagi penyalahgunaan narkotika. Selain merujuk pada pasal tersebut diatas, terdapat dua Surat Edaran Mahkamah Agung yakn SEMA No. 04 Tahun 2010 dan SEMA No. 03 Tahun 2011. Kedua SEMA diatas bisa dijadikan rujukan bagi hakim untuk memberikan rehabilitasi medis dan sosial.

Dijelaskan dalam SEMA No.03 tahun 2010 tentang Penempatan Penyalahgunaan , Korban Penyalahgunaan Dan Pecandu Narkotika KeDalam Lemabaga Rehabilitasi Medis dan Rehabilitasi Sosial yang mana dijelaskan bahwa penerapan pemidanaan sebagaimana dimaksud dalam Pasal 103 huruf a dan b Undang-undang Republik Indonesia Nomor 35 Tahun 2009 tentang Narkotika hanya dapat dijatuhkan pada klasifikasi tindak pidana sebagai berikut:

a) Terdakwa pada saat ditangkap oleh penyidik Polri dan penyidik BNN dalam kondisi tertangkap tangan ;

b) Pada saat tertangkap tangan sesuai butir a diatas ditemukan barang bukti pemakaian I (satu) hari dengan perincian an tara lain sebagai berikut : 
1. Kelompok metamphetamine (shabu) : 1 gram

2. Kelompok MDMA (ekstasi): 2,4 gram=8 butir

3. Kelompok Heroin:1,8gram

4. Kelompok Kokain:1,8gram

5. Kelompok Ganja5

6. Daun Koka:5gram

7. Meskalin:5 gram

8. Kelompok Psilosybin: 3 gram

9. Kelompok LSD (d-lysergic acid diethylamide :2 gram

10. Kelompok PCP (phencyclidine) : 3 gram

11. Kelompok Fentanil:1

12. Kelompok Metadon:0,5

13. Kelompok Morfin: 1,8

14. Kelompok Petidin:0,96 gram

15. Kelompok Kodein:72gram

16.Kelompok Bufrenorfin:32 mg

c. Surat uji Laboratorium positif menggunakan Narkotika berdasarkan permintaan penyidik.

d. Perlu Surat Keterangan dari dokter jiwaJpsikiater pemerintah yang ditunjuk oleh Hakim.

e. Tidak terdapat bukti bahwa yang bersangkutan terlibat dalam peredaran gelap Narkotika.

Selain SEMA diatas, juga terdapat SEMA No. 03 tahun 2011 . adapun latar belakang SEMA Tahun 2011 muncul dikarenakan jumlah angka penyalahgunaan Narkotika bagi diri sendiri khususnya semakin meningkat. Hal ini juga dikarenakan pemberlakuaan rehabilitasi medis dan rehabilitasi sosial tidak optimal. Selain itu jugasecara penerapan belum ada keterpaduan anatar aparat penegak hukum yang berdamapak pada minimnya pengobatan dengan rehabilitasi. DEngan adanya SEMA Tahun 2011, pada dasarnya hal ini mnegisyaratkan bahwa Mahkamah Agung menghimbau kepada aparat penegak hukum untu lebih mengoptimalisasikan pengobatan bagi penyalagunaan narkotika.

Kedua SEMA diatas dapat dijadikan rujukan bagi hakim untuk menjatuhkan putusan pidana berupa rehabilitasi medis dan sosial, akan tetapi secara penerapan dan meilhat dari tiga putusan hakim diatas maka akan sangat sulit bagi hakim menerepkan putusan rehabilitasi jika dalam hal ini dakwaan yang dibuat jaksa ternyata tidak menggunakan pasal 127 melainkan lebih pada 112, sehinggga dalam hal ini hakim hanya memeriksa dan mengadili kasus penyalahgunaan narkotika berdasarkan dakwaan yang diajukan jaksa. Hal inilah yang menurut penulis akan menghambat penerapan alternative pemidanaan selain pidana penjara. Jika dkaitkan dengan kebijakan criminal, maka perlu diketahui bahwa yang dimaksud 
kebijakan criminal adalah Sementara berkaitan dengan kebijakankriminalarc Ancel merumuskan bahwa kebijakan kriminal merupakan "The rational organitazion of the controlof crime by society". Bertolak dari pendapat-pendapat diatas maka cukup jelas kiranya bahwa kebijakan kriminal merupakan pengaturan atau penyusunansecara rasional usaha-usaha pengendalian kejahatan oleh masyarakat yang mana tujuan akhir dari kebijakan kriminal adalah "perlindungan masyarakat".

Dalam kaitannya dengan pemilihan rehabilitasi medis dan sosial , maka menurut penulis bahwa alternatif tersebut dapat dijadikan Usaha-usaha yang rasional untuk mengendalikan atau mengendalikan kejahatan (politik kriminal) sudah barang tentu tidak hanya menggunakan sarana "penal" (hukum pidana) tetapi juga sarana "non penal". Tujuan utama dari non penal itu adalah memperbaiki kondisi-kondisi sosial tertentu namun secara tidak langsung mempunyai pengaruh preventif terhadap kejahatan. Usaha-usaha non penal ini meliputi bidang sosial yang sangat luas sekali diseluruh bidang kebijakan sosial, misalnya penyantunan dan pendidikan sosila dalam rangka mengembangkan tanggung jawab sosial warga. ${ }^{10}$

Seperti yang sudah dijelaskan diatas bahwa kebijakan kriminal pada hakikatnya merupakan suatu usaha yang rasional dari masyarakat dalam menanggulangi kejahatan.Keterkaitan antara kebijakan kriminal dengan pidana bersyarat disini dapat dipahami bahwa dengan adanya pembaharuan hukum pidana yang memuat reorientasi dan reformasi terhadap sanksi pidana haruslah merupakan upaya penanggulangan yang bersifat terpadu,yakni tidak hanya dilihat dalam pembaharuan hukum pidana saja akan tetapi juga dapat dilihat dari sisi kebijakan kriminalnya.

\section{PENUTUP}

Dari analisa tersebut diatas, kesimpulan penulis adalah penjatuhan pidana penjara bagi pelaku penyalahgunaan narkotika bagi diri sendiri di Indonesia kurang tepat untuk dijatuhkan, hal ini tidak sesuai dengan tujuan pemidanaan yang hendak dicapai yakni berupa penanggulangan kejahatan dengan mencegah terjadinya tindak pidana dan memperbaiki diri pelaku. Penerapan penjatuhan alternative pemidanaan selain pidana penjara berupa rehabilitas medis dan rehabilitasi sosial susah untuk dijatuhkan hakim dalam tndak pidana penyalahgunaan narkotika bagi diri sendiri dikarenakan pasal yang dijeratkan tidak dimungkinkan diajtuhi putusan rehabilitasi. Dari kesimpulan tersebut maka penulis berpendaat perlu dilakukan revisi terhadap UU No. 35 Tahun 2009 khususnya berkenaan dengan pasal 112 tentang istilah memiliki, menguasai dan menyediakan karena memiliki pemaknaan yang bisa multitafsir.

\section{Daftar Pustaka}

\footnotetext{
${ }^{9}$ Barda Nawawi,Bunga Rampai Kebijakan Hukum Pidana, Jakarta, Kencana Kencana Prenada Media 2008 .Hal 1

${ }^{10}$ Ibid. Hal.40
} 


\section{Buku}

Ahmad Rifai, Penemuan Hukum Oleh Hakim Dalam Perspektif Hukum Progresif, Sinar Grafika, Jakarta, 2010.

Barda Nawawi. Kebijakan Hukum Pidana. Semarang. Kencana Prenada Media. 2008

Barda Nawawi Arief, Kapita Selekta Hukum Pidana, Bandung: Citra Aditya Bakti, 2010.

Muladi, Lembaga Pidana Bersyarat, Bandung: Alumni, 2004

Pontang, Pembentukan Hukum melalui Putusan Pengadilan Dalam Perkara Pidana, Bandung, Alumni, 2005.

Tongat, Pidana Kerja Sosial dalam Hukum Pidana Di Indonesia, Jakarta, Djambatan, 2002.

\section{Peraturan Perundang-undangan}

Undang-Undang Nomor 35 Tahun 2009 Tentang Tindak pidana Narkotika

Surat Edaran Mahkamah Agung Nomor 04 Tahun 2010

Surat Edaran Mahkamah Agung Nomor. 03 Tahun 2011

Putusan Pengadilan Negeri Malang Nomor 441/Pid.Sus/2017/PN-Mlg Tahun 2017

Putusan Pengadilan Negeri Malang Nomor 452/Pid.Sus/2017/PN-Mlg Tahun 2017

Putusan Pengadilan Negeri Malang Nomor 313/Pid.Sus/2017/PN-Mlg Tahun 2017 